University of Nebraska - Lincoln

DigitalCommons@University of Nebraska - Lincoln

USDA National Wildlife Research Center - Staff Publications
U.S. Department of Agriculture: Animal and Plant Health Inspection Service

2018

\title{
Persistence of maternal antibodies to influenza A virus among captive mallards (Anas platyrhynchos)
}

Katherine L. Dirsmith

USDA APHIS Wildlife Services, kdirsmit@gmail.com

J. Jeffrey Root

USDA APHIS Wildlife Services

Kevin T. Bentler

USDA APHIS Wildlife Services

Heather J. Sullivan

USDA APHIS Wildlife Services

Andrea B. Liebowitz

USDA APHIS Wildlife Services

See next page for additional authors

Follow this and additional works at: https://digitalcommons.unl.edu/icwdm_usdanwrc

Part of the Life Sciences Commons

Dirsmith, Katherine L.; Root, J. Jeffrey; Bentler, Kevin T.; Sullivan, Heather J.; Liebowitz, Andrea B.; Petersen, Lauren H.; McLean, Hailey E.; and Shriner, Susan A., "Persistence of maternal antibodies to influenza A virus among captive mallards (Anas platyrhynchos)" (2018). USDA National Wildlife Research Center - Staff Publications. 2203.

https://digitalcommons.unl.edu/icwdm_usdanwrc/2203

This Article is brought to you for free and open access by the U.S. Department of Agriculture: Animal and Plant Health Inspection Service at DigitalCommons@University of Nebraska - Lincoln. It has been accepted for inclusion in USDA National Wildlife Research Center - Staff Publications by an authorized administrator of DigitalCommons@University of Nebraska - Lincoln. 


\section{Authors}

Katherine L. Dirsmith, J. Jeffrey Root, Kevin T. Bentler, Heather J. Sullivan, Andrea B. Liebowitz, Lauren H. Petersen, Hailey E. McLean, and Susan A. Shriner 


\title{
Persistence of maternal antibodies to influenza A virus among captive mallards (Anas platyrhynchos)
}

\author{
Katherine L. Dirsmith ${ }^{1,2}$. J. Jeffrey $\operatorname{Root}^{1} \cdot K_{\text {Kevin T. Bentler }} \cdot$ Heather J. Sullivan ${ }^{1} \cdot$ Andrea B. Liebowitz $^{1}$. \\ Lauren H. Petersen ${ }^{1} \cdot$ Hailey E. McLean ${ }^{1}$ - Susan A. Shriner ${ }^{1}$
}

Received: 10 May 2018 / Accepted: 23 July 2018 / Published online: 21 August 2018

(c) This is a U.S. government work and its text is not subject to copyright protection in the United States; however, its text may be subject to foreign copyright protection 2018

\begin{abstract}
Wild waterfowl are maintenance hosts of most influenza A virus (IAV) subtypes and are often the subjects of IAV surveillance and transmission models. While maternal antibodies have been detected in yolks and in nestlings for a variety of wild bird species and pathogens, the persistence of maternal antibodies to IAVs in mallard ducklings (Anas platyrhynchos) has not been previously investigated. Nonetheless, this information is important for a full understanding of IAV transmission dynamics because ducklings protected by maternal antibodies may not be susceptible to infection. In this study, we examined the transfer of IAV-specific maternal antibodies to ducklings. Blood samples were collected approximately every five days from ducklings hatched from hens previously infected with an H6 strain of IAV. Serum samples were tested for antibodies to IAV by an enzyme-linked immunosorbent assay. The median persistence of maternal antibodies in ducklings was 12.5 days (range: 4-33 days) post-hatch. The majority of ducklings (71\%) had detectable maternal antibodies from 4 to 17 days post-hatch, while a small subset of individuals (29\%) had detectable maternal antibodies for up to 21-33 days post-hatch. Antibody concentrations in hens near the time of egg laying were correlated with maternal antibody concentrations in the initial blood sample collected from ducklings (0-4 days post-hatch). Knowledge of the duration of maternal antibodies in ducklings will aid in the interpretation of IAV serological surveillance results and in the modeling of IAV transmission dynamics in waterfowl.
\end{abstract}

\section{Introduction}

Influenza A viruses (IAV) significantly impact public and animal health, as well as agricultural economics [1]. Highly pathogenic H5 IAVs have proliferated and become endemic in wild birds since the emergence of Asian H5N1 in 1996. The recent emergence and global spread of 2.3.4.4 H5Nx

Handling Editor: Ayato Takada.

Electronic supplementary material The online version of this article (https://doi.org/10.1007/s00705-018-3978-4) contains supplementary material, which is available to authorized users.

Katherine L. Dirsmith

kdirsmit@gmail.com

1 National Wildlife Research Center, Animal and Plant Health Inspection Service, United States Department of Agriculture, Fort Collins, CO, USA

2 College of Veterinary Medicine and Biomedical Sciences, Colorado State University, Fort Collins, CO, USA viruses [2-4] combined with the ability of low-pathogenicity IAVs to mutate into highly pathogenic IAVs $[5,6]$ underscore the importance of understanding how influenza A viruses perpetuate and elicit immune responses in wild birds. Wild aquatic birds in the orders Anseriformes and Charadriiformes are the primary natural maintenance hosts of most IAV subtypes [7-10]. Dabbling ducks, including mallards (Anas platyrhynchos), are particularly prone to high IAV infection rates $[10,11]$. While IAVs are most commonly identified in poultry and waterfowl [12-14], they are also found in many other species that share mallard habitat, including passerines [15] and mammals [16, 17].

Studies of infection and transmission dynamics of IAV in waterfowl are dependent on information on the infection and immunological status of individuals. Very young animals may have circulating maternal antibodies passively acquired from their mothers. Often, these maternal antibodies are important to the survival of very young animals [18-22] while fledgling immune systems are developing. The presence of maternal antibodies may also affect 
overall population immunity and IAV infection dynamics by decreasing the number of susceptible individuals in a population $[23,24]$.

In chickens (Gallus gallus domesticus), which have received the most research attention, maternal antibodies to various antigens have been detected between 14 and 41 days post-hatch [25-28]. Influenza-specific studies in mallard and yellow-legged gull eggs have demonstrated maternal antibody transfer in wild birds and have shown that the concentration of circulating antibodies in mothers is correlated with the maternal antibody levels detected in egg yolks [24, 29].

In the current study, we investigated the transfer and persistence of maternal anti-IAV antibodies in mallards. We studied associations between maternal antibody levels in ducklings and antibody persistence, hen circulating antibody levels near the time of hatch, and nest attempt. The primary goal of the study was to investigate the presence and persistence of maternal anti-IAV antibodies in ducklings to further our understanding of how maternal antibodies may play a role in influenza A virus dynamics.

\section{Materials and methods}

\section{Study animals}

Flying mallards were obtained at two days of age from a commercial avian hatchery (Murray McMurray Hatchery, Inc. Webster City, IA) and were housed in quarantine facilities for two weeks and later maintained in a large outdoor flight pen $(18.5 \mathrm{~m} \times 38.0 \mathrm{~m})$ prior to testing (Fig. 1). Oral, cloacal, fecal, and blood samples were collected from all ducks prior to study initiation to detect any current or previous IAV infection. All studies were approved by the Institutional Animal Care and Use Committee of the United States Department of Agriculture National Wildlife Research Center (NWRC), Fort Collins, CO, USA (NWRC, Approval QA-1912). All indoor pens were equipped with ad libitum food and water and an artificial pond. The outdoor flight pen was equipped with ad libitum food and water, artificial ponds, wooden shelters, and heat lamps during cold weather.
Fig. 1 Outdoor Flight Pen Experimental Setup. a) Birds were housed in a large $18.5 \mathrm{~m}$ $\times 38$ m outdoor flight pen. b) Most nests hatched synchronously in a single day. c) A mallard hen incubating eggs. d) Mallard ducklings follow a hen into a shelter. e) A mallard duckling
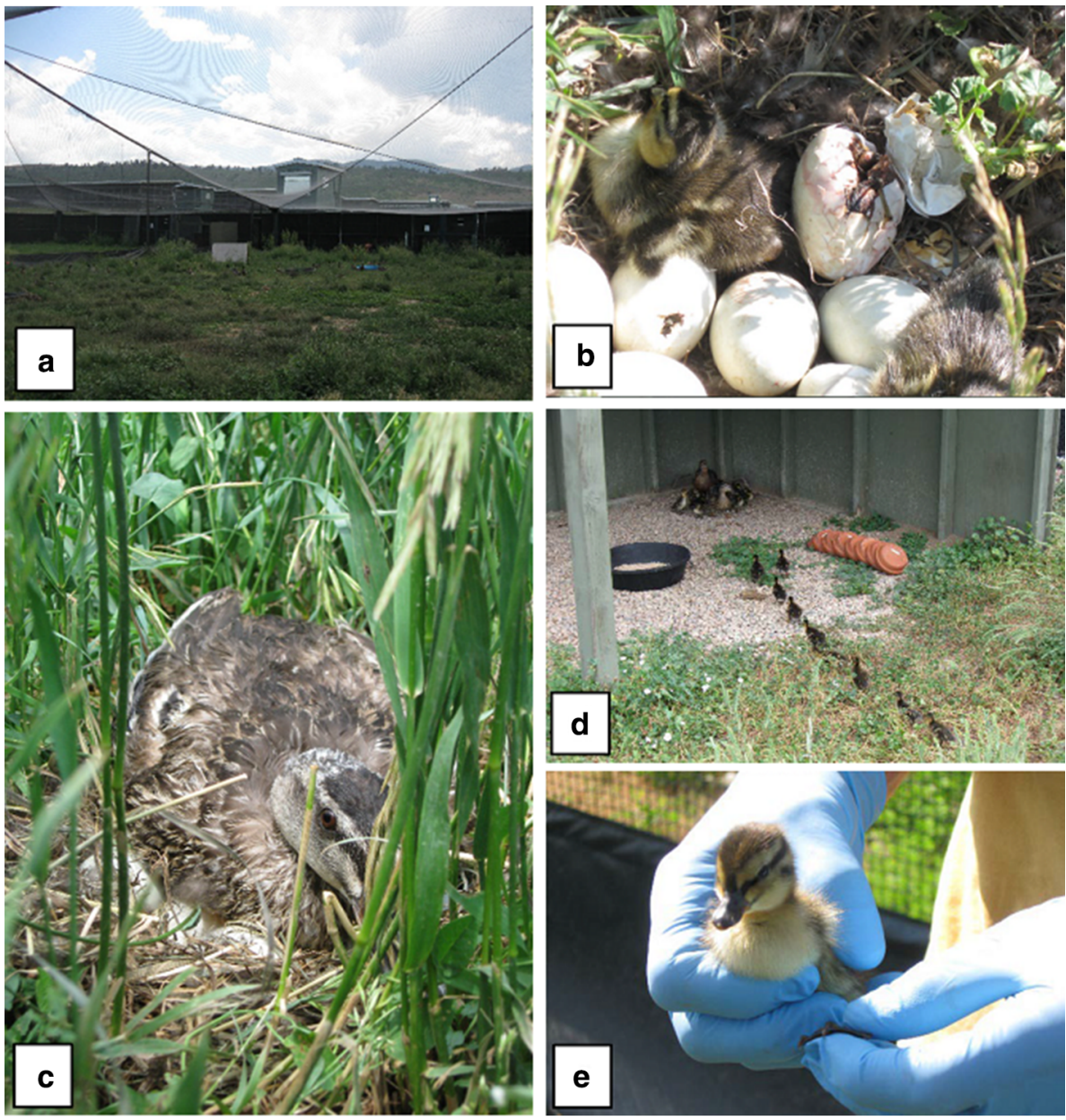


\section{Virus propagation}

A North American endemic IAV [A/wild bird/IL/18398324/06(H6N2)] of the family Orthomyxoviridae was collected during a national avian IAV surveillance program of wild birds in the United States that began in 2006 [8]. This virus was propagated in the allantoic cavities of nine 11-day-old specific-pathogen-free embryonated hen eggs using standard methods [30]. The Reed and Muench method was used to calculate viral titers [31].

\section{Experimental inoculation and rechallenge}

Forty six-month old birds (one-half male and one-half female) were successfully infected either by choanal inoculation with $10^{3} \mathrm{EID}_{50}$ of H6N2 IAV per mL or by contact with an infected duck. Approximately a year later, all ducks were rechallenged with $10^{3} \mathrm{EID}_{50}$ of H6N2 per mL, and exposure was confirmed by enzyme-linked immunosorbent assay (ELISA). Ducks were transferred to an outdoor flight pen following confirmation that all individuals were free of virus. Sentinel mallards that had not been previously exposed to avian influenza virus were also housed in the flight pen, and blood samples were collected from all birds approximately monthly to ensure that no additional IAV exposures occurred.

\section{Nesting}

Twenty female and 17 male mallards were allowed to breed naturally in an outdoor flight pen at approximately two years of age (six months after their second IAV exposure). Four IAV-antibody-negative sentinel mallards (two females and two males) also remained in the outdoor pen and were allowed to nest. Mowing in the pen was suspended so vegetation could grow to provide natural cover for nesting. Monthly blood sampling of adult mallards occurred from June to October 2014. The flight pen was searched daily to identify nests, as well as to track nest location, size, and hen association. Hens were allowed to re-nest after either nest success or failure. Eggs hatched between July 1, 2014 and October 16, 2014. Ducklings were banded on the same day they hatched, and hatch dates were recorded for each individual. Blood samples of approximately $75-100 \mu \mathrm{L}$ were collected from each duckling, generally at 0-4 days posthatch. Each duckling was then sampled approximately every five days until it consistently tested negative for antibodies to IAV.

\section{PCR and ELISA}

IAV infections in the adult mallards were confirmed by testing oral, cloacal, and fecal samples for IAV RNA by real-time reverse transcription polymerase chain reaction (qRT-PCR). RNA was extracted using a MagMAX-96 AI/ ND Viral RNA Isolation Kit (Thermo Fisher Scientific, Inc., Waltham, MA), and qRT-PCR was performed as described previously [32] .

All blood samples were collected in serum separator tubes, centrifuged to collect serum, and stored at approximately $4{ }^{\circ} \mathrm{C}$ until testing. The serum was tested for the presence of anti-IAV antibody by an ELISA using the IDEXX AI MultiS-Screen Ab Test (IDEXX AI MultiS-Screen, Westbrook, Maine). Samples were considered positive for the presence of anti-IAV antibody for sample-to-negative $(\mathrm{S} / \mathrm{N})$ ratios less than 0.70 [33]. Although the manufacturer suggests using an $\mathrm{S} / \mathrm{N}$ ratio threshold of 0.5 to distinguish positive from negative samples, extensive testing has shown that an $\mathrm{S} / \mathrm{N}$ threshold of 0.7 maximizes correct sample classification for use in mallards [33, 34].

\section{Analyses}

Hen and duckling nesting and serology data were collated, and all statistical analyses were performed using $\mathrm{R}$ software [35]. Antibody persistence was calculated for each individual duckling as the midpoint between the first day it was positive by ELISA and the first day that it was negative at two successive sampling points. A potential correlation between hen antibody levels near the time of laying and the first duckling antibody level measured (0-4 days post-hatch) was investigated using a mixed model, utilizing the package lme [36]. Initial duckling maternal antibody levels for ducklings hatched from first clutches were modeled as a function of hen antibody level and day post-hatch (to account for potential differences in duckling antibody levels, since initial sampling varied from 0 to 4 days post-hatch among the ducklings). The hen associated with a duckling was included as a random effect (to account for the lack of independence for nestmates). We also tested whether duckling antibody levels at first sampling were associated with persistence, using a mixed effects model where persistence was modeled as a function of initial duckling antibody level and clutch, with hen as a random effect.

\section{Results}

We sampled a total of 113 ducklings from 24 nests and 17 females. The flight pen where the mallards were housed prevented access from most animals; however, small rodents and snakes were able to enter the pen. Consequently, we lost several nests and many eggs due to predation by bull snakes (Pituophis catenifer) during the first month of the study. One of the successful nests belonged to a sentinel female who was negative for antibodies against IAV throughout the 
study, and her six hatchlings were also negative for anti-IAV antibodies. Of the remaining 23 successful nests, 13 were first attempts, nine were second clutches, and one nest was a third clutch.

All 107 ducklings from previously infected hens were positive for anti-IAV maternal antibodies at first sampling based on ELISA S/N ratios. One duckling was just above the $\mathrm{S} / \mathrm{N}$ ratio threshold on day four post-hatch, and one was negative on day five, but all others were positive for at least a week post-hatch. Overall, ducklings remained positive for antibodies to IAV for a median of 12.5 days (Fig. 2), with a minimum persistence of four days and a maximum persistence of 33 days. Although the majority of ducklings (71\%) did not have detectable maternal antibodies past 17 days post-hatch, maternal antibodies were still circulating for up to 21 to 33 days post-hatch in the remaining $29 \%$ of ducklings, resulting in a right-skewed distribution of persistence
(Fig. 2). Antibody persistence was significantly correlated with initial duckling antibody levels ( $\mathrm{S} / \mathrm{N}$ ratios, $t$-value $=$ -3.275 for 102 observations and 13 groups).

In general, antibody levels were elevated for the first two days post-hatch and then decreased at a nonlinear rate over time (Fig. 3), with an asymptote at approximately 17 days post-hatch. The median antibody level was negative at 16 days post-hatch and remained negative for the remainder of the testing period (48 days post-hatch). Nonetheless, antibody responses showed significant heterogeneity, with some individuals exhibiting detectable maternal antibodies for nearly five weeks post-hatch.

Hen antibody levels were positively correlated with duckling maternal antibody levels (duckling levels from 0 to 4 days post-hatch for first attempt nests, $t$-value $=3.671$ for 48 observations and 12 nests, Fig. 4). Accounting for the day post-hatch on which sampling occurred (i.e., 0-4 days)
Fig. 2 Histogram of antibody persistence in mallard ducklings. The plot shows the distribution of maternal antibody durations (i.e., how many days a duckling was positive for antibodies to influenza A virus after hatching). Each bar represents the number of ducklings associated with each persistence duration
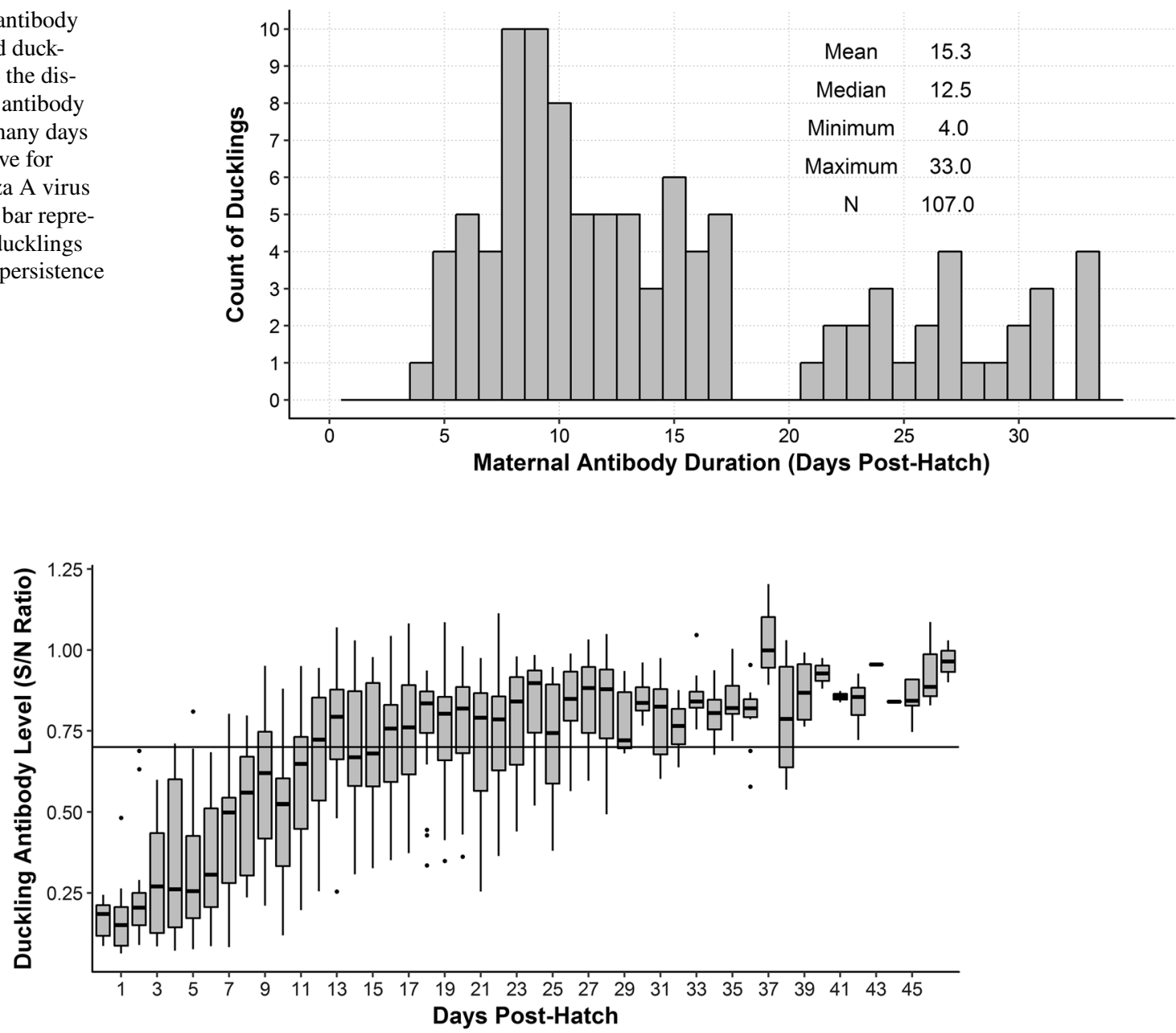

Fig. 3 Boxplots of maternal antibody concentrations over time for ducklings hatched from hens previously infected with influenza A virus. Each duckling was sampled approximately once every five days, and therefore the boxplot for each day post-hatch is based on the ducklings sampled on a particular day post-hatch. Concentrations are expressed as sample-to-negative $(\mathrm{S} / \mathrm{N})$ ratios obtained using a commercial blocking ELISA; values $<0.70$ are considered positive. Each box shows the interquartile range (IQR, middle $50 \%$ of values), horizontal bars are medians, and vertical lines are values within $1.5 * \mathrm{IQR}$. Outliers are plotted as individual points 


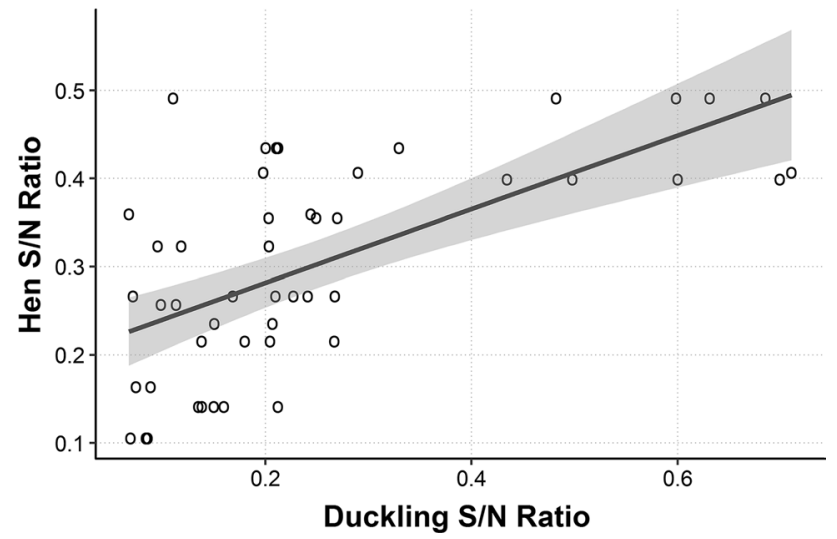

Fig. 4 Hen and duckling influenza A virus antibody levels. Hen antibody levels were positively correlated with duckling maternal antibody levels for the initial blood samples collected from each duckling (0-4 days post-hatch)

also showed a significant impact on duckling antibody levels $(t$-value $=3.447)$. While there was a correlation between hen and duckling antibody levels, there was substantial variability associated with ducklings with high antibody levels $(\mathrm{S} / \mathrm{N}$ ratios $<0.30)$.

Because ducklings were removed from the flight pen once they consistently tested negative for maternal antibodies, various hens laid multiple nests throughout the study. On average, ducklings from later nest attempts had somewhat lower antibody levels compared to those from first nest attempts, but the relationship was not statistically significant $(t$-value $=0.191)$. Of the seven females that renested, mean duckling antibody level within a nest was similar or lower for second clutches for six of seven hens but was higher for the second clutch of one of the hens.

\section{Discussion}

Similar to previous studies of IAV-specific maternal antibodies in other species [24, 27, 37-39], we found a significant correlation between hen circulating antibody levels near the time of egg laying and the maternal antibody levels in ducklings within the first few days of hatching. While we did not find a significant correlation between nest attempt and maternal antibody level in ducklings, antibody levels in hens and ducklings were slightly lower for second clutches compared to first clutches.

All ducklings from hens previously infected with IAV had detectable maternal antibodies, with a median persistence time of 12.5 days and a range of 4-33 days. The distribution of persistence durations was approximately normal for about $70 \%$ of individuals, with a mean around 10 days post-hatch (Fig. 2), but nearly one-third of the ducklings had longer persistence times, with several individuals positive through 33 days. Accordingly, most ducklings from previously exposed hens are likely to experience some level of protection for one to two weeks, but a smaller subset of individuals have detectable maternal antibodies for three to five weeks. Limited data have been published on infections in very young birds, but at least one study documented IAV infections in wild ring-billed gulls as young as three to five weeks old [40]. Consequently, maternal antibodies may play an important role in IAV dynamics when viruses circulate among very young birds.

While we found that maternal antibody persistence was correlated with initial duckling antibody levels (which were in turn associated with hen antibody levels), we also observed significant heterogeneity in the relationship, as evidenced by the right-skewed distribution of persistence (Fig. 2). Thus, while antibody levels within a few days of hatching were correlated with persistence, other factors may also influence persistence, such as rate of development or body condition. All of the hens and ducklings in our experiment had food available ad libitum; however, we observed differences in how quickly ducklings became adept at foraging and drinking. While most of the heterogeneity we observed was between nests, we also observed significant differences in antibody duration within a few nests. This heterogeneity within our study may have been due to the presence of egg dumping by some females [24, 41] such that some of the ducklings may have been misclassified to the incorrect female. The birds in our study were provided ample nesting space, but prime vegetative cover was somewhat limited such that several hens laid clutches adjacent to each other and may have deposited eggs in others' nests. Other potential factors may have included differences in nest initiation date during the study period, as well as variability between first and second clutches. Regardless, individual heterogeneity in the persistence of antibodies is a common observation in birds [42].

Most studies evaluating maternal antibodies in birds have been conducted in poultry. Across multiple pathogens in chickens, maternal antibodies have been detected for 14 to 41 days post-hatch [25-27, 43, 44]. Consistent with those findings, a study on IAV-specific maternal antibodies in chickens found that maternal antibodies persisted for approximately 34 days in chicks hatched to hens exposed to a recombinant IAV vaccine [28]. Most of the ducklings in our study exhibited much shorter persistence durations, but several individuals did show antibody persistence durations of more than thirty days. No other data are available on IAVspecific maternal antibodies in wild birds, since the studies that have reported on IAV-specific maternal antibodies have focused on antibodies found in egg yolks rather than hatched nestlings.

Published studies on IAV maternal antibodies in wild birds have assessed gulls, mallards, and white-winged terns 
(Chlidonias leucopterus). Three studies have been published on yellow-legged gulls (Larus michahellis) [29, 39, 45]. The first study [45] found 14\% of yellow-legged gull eggs from wild birds had anti-IAV antibodies, the second study [29] evaluated both adults and egg yolks and found lower antibody prevalence in egg yolks from later nests (possibly because later-nesting gulls are younger and have experienced fewer exposures), and the third study [39] showed a correlation between female antibody levels and maternal antibodies in the yolks of their eggs as well as a correlation between maternal antibody levels in yolks and egg-laying order. A study investigating the prevalence of maternal antibodies in egg yolks of wild mallards and white-winged terns revealed that the prevalence of $\mathrm{H} 1$ and $\mathrm{H} 3$ subtype-specific antibodies was higher than that of $\mathrm{H} 5$ and $\mathrm{H} 7$ subtype-specific antibodies. The highest prevalence of $\mathrm{H} 1$ subtype-specific antibodies $(11 \%)$ was identified in mallard egg yolks [46]. Collectively, these studies demonstrate that maternal antibodies are likely to be common in newly hatched birds of wild species frequently exposed to IAVs and underscore the importance of understanding maternal antibodies in common maintenance hosts such as mallards.

The other primary study on IAV-specific maternal antibodies in wild birds examined both wild and captive mallards [24]. For wild mallards, nearly half (48\%) of females and $43 \%$ of their corresponding eggs had detectable antiIAV antibodies. In contrast, $56 \%$ of females, and only $24 \%$ of eggs, had antibodies in captive mallards. A potential difference between the wild mallards and the captive mallards in that study may have been the number of IAV exposures for hens if the wild mallards experienced comparatively more exposures. Multiple exposures lead to anamanestic immune responses, which result in higher antibody levels. Thus, on average, wild mallards may have had elevated antibody levels with corresponding higher levels of maternal antibody transfer. In our captive mallards, hens were twice exposed to IAV and as such had higher antibody levels compared to a single exposure [47]. The higher antibody level associated with an anamnestic response likely increases maternal antibody transfer. Since mallards are known to be frequently exposed to IAVs in the wild, elevated antibody levels due to multiple exposures is likely to be common, such that high rates of maternal antibody transfer to ducklings is expected for wild mallards. Future investigation into the dynamics of avian influenza maternal antibody transfer in other wild bird species will help further inform interpretation of serological surveillance results in wild birds.

\section{Conclusions}

This study provides novel information on IAV maternal antibody persistence in mallards and adds to our understanding of potential factors that may affect maternal antibody transfer in an imporatant IAV maintenance host. This information is essential to IAV sero-surveillance efforts in order to better discern between maternal antibodies and antibodies circulating in response to an IAV infection. In addition, the information on maternal antibody kinetics provided by our study adds to our understanding of seasonal patterns of influenza prevalence in waterfowl $[48,49]$ and has the potential to improve the timing of surveillance sample collection for detecting highly pathogenic IAVs in wild water birds. Moreover, the data from this study can be used in disease dynamic models to properly account for the impact of maternal antibodies in IAV transmission.

Acknowledgements We thank the National Wildlife Research Center Animal Care staff for animal husbandry and veterinary care, and Kaci VanDalen, Jeremy Ellis, Nick Dannemiller, and Molly Selleck for assistance in data collection. In addition, we thank Kaci VanDalen for manuscript review, and Enrique Doster for assistance with data analysis. The USDA endorses no commercial products used in this study.

Data availability All data generated or analysed during this study are included in this published article and its supplementary information file (Online Resource 1).

\section{Compliance with ethical standards}

Welfare of animals All applicable national and institutional guidelines for the care and use of animals were followed. All procedures performed in studies involving animals were in accordance with the ethical standards of the institution at which the studies were conducted. The study was conducted under NWRC IACUC Approval QA-1912.

Conflict of interest The authors declare that they have no conflict of interest.

Funding This study was funded by the United States Department of Agriculture, Animal and Plant Health Inspection Service, Wildlife Services.

\section{References}

1. Paarlberg PL, Seitzinger AH, Lee JG (2007) Economic impacts of regionalization of a highly pathogenic avian influenza outbreak in the United States. J Agric Appl Econ 39(2):325-333

2. Brand JM, Verhagen JH, Kroeze EJV, Bildt MW, Bodewes R, Herfst S, Richard M, Lexmond P, Bestebroer TM, Fouchier RA (2018) Wild ducks excrete highly pathogenic avian influenza virus H5N8 (2014-2015) without clinical or pathological evidence of disease. Emerg Microbes Infect 7(1):67. https://doi.org/10.1038/ s41426-018-0070-9

3. Duan L, Bahl J, Smith G, Wang J, Vijaykrishna D, Zhang L, Zhang J, Li K, Fan X, Cheung C (2008) The development and genetic diversity of H5N1 influenza virus in China, 1996-2006. Virol 380(2):243-254

4. Gilbert M, Koel BF, Bestebroer TM, Lewis NS, Smith DJ, Fouchier RA (2014) Serological evidence for non-lethal exposures of Mongolian wild birds to highly pathogenic avian influenza H5N1 virus. PLoS ONE 9(12):e113569 
5. Seekings A, Slomka M, Russell C, Howard W, Choudhury B, Nuñéz A, Löndt B, Cox W, Ceeraz V, Thorén P (2018) Direct evidence of $\mathrm{H} 7 \mathrm{~N} 7$ avian influenza virus mutation from low to high virulence on a single poultry premises during an outbreak in free range chickens in the UK, 2008. Infect Genet Evol 64:13-31

6. Dietze K, Graaf A, Homeier-Bachmann T, Grund C, Forth L, Pohlmann A, Jeske C, Wintermann M, Beer M, Conraths FJ (2018) From low to high pathogenicity-characterization of H7N7 avian influenza viruses in two epidemiologically linked outbreaks. Transbound Emerg Dis. https://doi.org/10.1111/tbed.12906

7. Hinshaw V, Webster R, Turner B (1980) The perpetuation of orthomyxoviruses and paramyxoviruses in Canadian waterfowl. Can J Microbiol 26(5):622-629

8. Deliberto TJ, Swafford SR, Nolte DL, Pedersen K, Lutman MW, Schmit BB, Baroch JA, Kohler DJ, Franklin A (2009) Surveillance for highly pathogenic avian influenza in wild birds in the USA. Integr Zool 4(4):426-439

9. Stallknecht DE, Brown JD, Swayne D (2008) Ecology of avian influenza in wild birds. Avian Influenza 1:43-58

10. Webster RG, Bean WJ, Gorman OT, Chambers TM, Kawaoka Y (1992) Evolution and ecology of influenza A viruses. Microbiol Rev 56(1):152-179

11. Olsen B, Munster VJ, Wallensten A, Waldenström J, Osterhaus AD, Fouchier RA (2006) Global patterns of influenza A virus in wild birds. Science 312(5772):384-388

12. Spackman E, Stallknecht DE, Slemons RD, Winker K, Suarez DL, Scott M, Swayne DE (2005) Phylogenetic analyses of type A influenza genes in natural reservoir species in North America reveals genetic variation. Virus Res 114:89-100

13. Chin P, Hoffmann E, Webby R, Webster R, Guan Y, Peiris M, Shortridge K (2002) Molecular evolution of H6 influenza viruses from poultry in southeastern China: prevalence of $\mathrm{H} 6 \mathrm{~N} 1$ influenza viruses possessing seven A/Hong Kong/156/97 (H5N1)-like genes in poultry. J Virol 76(2):507-516

14. Woolcock P, Suarez D, Kuney D (2003) Low-pathogenicity avian influenza virus (H6N2) in chickens in California, 2000-02. Avian Dis $47: 872-881$

15. Ip HS, Flint PL, Franson JC, Dusek RJ, Derksen DV, Gill RE, Ely CR, Pearce JM, Lanctot RB, Matsuoka SM (2008) Prevalence of influenza A viruses in wild migratory birds in Alaska: patterns of variation in detection at a crossroads of intercontinental flyways. Virol J 5(1):71

16. Reperant L, Rimmelzwaan G, Kuiken T (2009) Avian influenza viruses in mammals. Rev Sci Tech 28(1):137

17. Vandalen KK, Shriner SA, Sullivan HJ, Root JJ, Franklin AB (2009) Monitoring exposure to avian influenza viruses in wild mammals. Mamm Rev 39(3):167-177

18. Hasselquist D, Nilsson J- $\AA$ (2009) Maternal transfer of antibodies in vertebrates: trans-generational effects on offspring immunity. Phil Trans R Soc Lond B Biol Sci 364(1513):51-60

19. Grindstaff JL (2008) Maternal antibodies reduce costs of an immune response during development. J Exp Biol 211(5):654-660

20. Heeb P, Werner I, Kölliker M, Richner H (1998) Benefits of induced host responses against an ectoparasite. Proc R Soc Lond B Biol Sci 265(1390):51-56

21. Buechler K, Fitze P, Gottstein B, Jacot A, Richner H (2002) Parasite-induced maternal response in a natural bird population. $\mathrm{J}$ Anim Ecol 71(2):247-252

22. Gustafsson E, Mattsson A, Holmdahl R, Mattsson R (1994) Pregnancy in B-cell-deficient mice: postpartum transfer of immunoglobulins prevents neonatal runting and death. Biol Reprod 51(6):1173-1180

23. Boulinier T, Staszewski V (2008) Maternal transfer of antibodies: raising immuno-ecology issues. Trends Ecol Evol 23(5):282-288
24. van Dijk JG, Mateman AC, Klaassen M (2014) Transfer of maternal antibodies against avian influenza virus in mallards (Anas platyrhynchos). PLoS ONE 9(11):e112595

25. Fahey K, Crooks J, Fraser R (1987) Assessment by ELISA of passively acquired protection against infectious bursal disease virus in chickens. Aust Vet J 64(7):203-207

26. Darbyshire J, Peters R (1985) Humoral antibody response and assessment of protection following primary vaccination of chicks with maternally derived antibody against avian infectious bronchitis virus. Res Vet Sci 38(1):14-21

27. Hamal KR, Burgess SC, Pevzner I, Erf G (2006) Maternal antibody transfer from dams to their egg yolks, egg whites, and chicks in meat lines of chickens. Poult Sci 85(8):1364-1372

28. Mesonero A, Suarez DL, Van Santen E, Tang DC, Toro H (2011) Avian influenza in ovo vaccination with replication defective recombinant adenovirus in chickens: vaccine potency, antibody persistence, and maternal antibody transfer. Avian Dis 55(2):285-292

29. Hammouda A, Pearce-Duvet J, Chokri MA, Arnal A, GauthierClerc M, Boulinier T, Selmi S (2011) Prevalence of influenza A antibodies in yellow-legged gull (Larus michahellis) eggs and adults in southern Tunisia. Vector-Borne Zoonotic Dis 11(12):1583-1590

30. Balish AL, Katz JM, Klimov AI (2013) Influenza: propagation, quantification, and storage. Curr Protoc Microbiol 29(1): 15G.1.1-15G.1.24

31. Reed LJ, Muench H (1938) A simple method of estimating fifty percent endpoints. Am J Epidemiol 27(3):493-497

32. VanDalen KK, Franklin AB, Mooers NL, Sullivan HJ, Shriner SA (2010) Shedding light on avian influenza H4N6 infection in mallards: modes of transmission and implications for surveillance. PLoS ONE 5(9):e12851

33. Shriner SA, VanDalen KK, Root JJ, Sullivan HJ (2016) Evaluation and optimization of a commercial blocking ELISA for detecting antibodies to influenza A virus for research and surveillance of mallards. J Virol Methods 228:130-134

34. Brown JD, Stallknecht DE, Berghaus RD, Luttrell MP, Velek K, Kistler W, Costa T, Yabsley MJ, Swayne D (2009) Evaluation of a commercial blocking enzyme-linked immunosorbent assay to detect avian influenza virus antibodies in multiple experimentally infected avian species. Clin Vaccine Immunol 16(6):824-829

35. R Development Core Team (2015) R: A Language and Environment for Statistical Computing. R Foundation for Statistical Computing, Vienna, Austria. https://www.R-project.org

36. Bates D, Mächler M, Bolker B, Walker S (2014) Fitting linear mixed-effects models using lme4. J Stat Softw 67:1-48. https:// doi.org/10.18637/jss.v067.i01

37. Grindstaff JL, Demas GE, Ketterson ED (2005) Diet quality affects egg size and number but does not reduce maternal antibody transmission in Japanese quail Coturnix japonica. J Anim Ecol 74(6):1051-1058

38. Faulkner OB, Estevez C, Yu Q, Suarez DL (2013) Passive antibody transfer in chickens to model maternal antibody after avian influenza vaccination. Vet Immunol Immunopathol 152:341-347

39. Hammouda A, Selmi S, Pearce-Duvet J, Chokri MA, Arnal A, Gauthier-Clerc M, Boulinier T (2012) Maternal antibody transmission in relation to mother fluctuating asymmetry in a longlived colonial seabird: the yellow-legged gull Larus michahellis. PLoS ONE 7(5):e34966

40. Velarde R, Calvin SE, Ojkic D, Barker IK, Nagy É (2010) Avian influenza virus $\mathrm{H} 13$ circulating in ring-billed gulls (Larus delawarensis) in southern Ontario, Canada. Avian Dis 54:411-419

41. Geffen E, Yom-Tov Y (2001) Factors affecting the rates of intraspecific nest parasitism among Anseriformes and Galliformes. Anim Behav 62(6):1027-1038 
42. Grindstaff JL (2010) Initial levels of maternally derived antibodies predict persistence time in offspring circulation. J Ornithol 151(2):423-428

43. Patterson R, Youngner J, Weigle W, Dixon F (1962) The metabolism of serum proteins in the hen and chick and secretion of serum proteins by the ovary of the hen. J Gen Phys 45(3):501-513

44. Kaleta E, Siegmann O, Lai K, Aussum D (1977) Kinetics of NDV-specific antibodies in chickens. VI. Elimination of Maternal and Injected Antibodies. Berl Munch Tierarztl Wochenschr 90:131-134

45. Pearce-Duvet JM, Gauthier-Clerc M, Jourdain E, Boulinier T (2009) Maternal antibody transfer in yellow-legged gulls. Emerg Infect Dis 15(7): 1147

46. Chen X, Qi Y, Wang H, Wang Y, Wang H, Ni H (2018) Prevalence of multiple subtypes of avian influenza virus antibodies in egg yolks of mallard (Anas platyrhynchos) and white-winged terns
(Chlidonias leucopterus) in the northeastern Republic of China. J Wildl Dis. https://doi.org/10.7589/2017-10-253

47. Pepin KM, Kay SL, Golas BD, Shriner SS, Gilbert AT, Miller RS, Graham AL, Riley S, Cross PC, Samuel MD (2017) Inferring infection hazard in wildlife populations by linking data across individual and population scales. Ecol Lett 20(3):275-292

48. Munster VJ, Baas C, Lexmond P, Waldenström J, Wallensten A, Fransson T, Rimmelzwaan GF, Beyer WE, Schutten M, Olsen B (2007) Spatial, temporal, and species variation in prevalence of influenza A viruses in wild migratory birds. PLoS Pathog 3(5):e61. https://doi.org/10.1371/journal.ppat.0030061

49. Segovia KM, Stallknecht DE, Kapczynski DR, Stabler L, Berghaus RD, Fotjik A, Latorre-Margalef N, França MS (2017) Adaptive heterosubtypic immunity to low pathogenic avian influenza viruses in experimentally infected mallards. PLoS ONE 12(1):e0170335. https://doi.org/10.1371/journal.pone.0170335 